\title{
CORRESPONDENCE.
}

PARNASSIUS CLODIUS AND P. SMINTHEUS.

SIR,-Good specimens of these species are generally easily separated, but occasionally specimens are taken the identity of which it is difficult to decide. Mr. C. de Blois-Green, of Victoria, B. C., who has taken both specimens in large numbers, has drawn my attention to a character which he finds reliable in all instances. This is that in Clodius the antennæe are uniformly black, whilst in Smintheus they are ringed with. white. Of course, when the abdominal pouch is attached, there is no difficulty in separating the female of Clodius with its large pouch from Smintheus with its small keel-shaped appendage. The value of these abdominal pouches has been well-worked out by Mr. H. J. Elwes in an exhaustive paper published in the Transactions of the Entomological Society of London. Some specimens received from Mr. de Blois-Green were sent to Dr. H. Strecker, and his opinion asked as to the value of the character based on the colour of the antennæ. His reply, which I think will be read with interest by lepidopterists, is as follows :-

"Your letter and the remnants of the Parnassius received. The latter are only Clodius, of the form found in the State of Washington and western British Columbia; those further south (California) are not as large nor as brightly coloured, as a general thing. Your correspondent is right in laying stress on the black antennæ. Clodius belongs to a group and is allied to some sub-group having black antennæ and large pouches. They embrace Nordmanni, from Armenia; Clarius, from W. Siberia; Eversmanni, from Alaska and Siberia; Felderi, the Amoor; Mnemosyne, Germany and Switzerland, etc.; Stubendorfii, Siberia ; and Glacialis, Japan ; whereas Smintheus has white-ringed antennæ, and its allies, distinguished further by the keel-shaped pouch, are Apollo, Germany ; Hesebolus, Mongolia, etc. ; Nomion, Siberia ; Jacquemonti, Himalayahs, etc., with white-ringed antennæ also; but there are sub-groups allied to these with the same keel-like pouch as Apollinus, Tartary; Honrathi, Turkestan, etc., that have all black antennæ, so there is no rule without an exception. Our Parnassius, according to my views, are but three species :-

I. Smintheus, Dbldy-Hew.

2. Clodius, Men.

3. Eversmanni, Men. 
All the others, such as Thor, Menetriesii, etc., are but varieties or aberrants. It would be easy to make fifty such species of Smintheus alone, if you took them at various altitudes and locations. Some butterflies, as, for instance, Papilio Turnus, of which I have great giants from North Carolina, Georgia, etc., expanding $5 \%$ inches, while others from the White Mountains spread only $2 \mathrm{x} / 2$ inches, and there are all sorts of shades of yellow, orange, brown and black, and yet who would think of making a dozen species of these? I notice that Mr. W. H. Edwards includes Par. Nomion in our fauna, I think somehow he must be mistaken, unless possibly it was caught in Alaska."

\section{Herman Strecker."}

Feeling sure that the above letter will be of interest to many of our readers, I have obtained Dr. Strecker's permission to publish it.

James Fletcher, Ottawa.

\section{UNIDENTIFIED BOMBYCIDS.}

Sir,---Messrs. Dyar and Neumoegen have struck a snag in their work, according to their statement in CAN. ENT. for May, 1893 . I am glad. that I am able to help them over one part of it. Of the " unidentified names," Saligena personata has been long since referred as a synonym of Raphia frater, and I am able to confirm the correctness of the reference. So Edema obliqua has been proved a noctuid, and an Arzama. As Sphidia or Arzama obliquata, it is a well-known insect. Messrs Neumoegen and Dyar are following Mir. Kirby's use of generic terms very closely. It would be a matter of some interest if they would inform us whether, in the case of Hübner's Tentamen, they have independently concluded that it should be adopted, or whether they simply follow $\mathrm{Mr}$. Kirby without original investigation. So few of the working entomologists have accepted the Tentamen as authority, that it is not impertinent to ask why they have joined the minority. Joun B. Smith.

PROF. C. H. 'IYLER TOWNSEND

has been appointed Curator of the Museum at the Institute of Jamaica, in place of Mr. T. D. A. Cockerell, who has recently resigned" on account of ill-health. Mr. Townsend's address is now Kingston, Jamaica, West Indies. We wish him much success and prosperity in his new position, and trust that he will continue to favour us with his valuable communications.

$$
\text { Mailed June I 2th. }
$$

